Check for updates

Cite this as: $B M J 2021 ; 374: \mathrm{n} 1774$ http://dx.doi.org/10.1136/bmj.n1774 Published: 12 July 2021

\section{The covid-19 lab leak hypothesis: did the media fall victim to a misinformation campaign?}

Box 2 in this feature article (BMJ 2021;374:n1656, doi:) has been updated to clarify an earlier version which reported that China had notified the World Health Organization on 31 December 2019 of cases of pneumonia of unknown aetiology in Wuhan City. As The BMJ does not know by which route WHO was first notified of the cases, the article now reads, "31 December 2019: WHO is notified of cases of pneumonia of unknown aetiology in Wuhan City." 